\title{
Characterization of soil permeability in the former Lake Texcoco, Mexico
}

https://doi.org/10.1515/geo-2019-0010

Received September 20, 2018; accepted January 10, 2019

\begin{abstract}
The geotechnical subsoil conditions of the former Lake Texcoco represent a complex sequence of highly compressible lacustrine clays interbedded with layers and seams of harder and more permeable materials. Although the mechanical properties of these deposits have been extensively studied in the past, the information about their hydraulic properties is scarce. Currently, a comprehensive characterization of the hydraulic conductivity of this site has become necessary because of the construction of the New Mexico International Airport (NAIM). The present study describes a systematic evaluation of the hydraulic conductivity in the former Lake Texcoco through three different in-situ methods (well permeameter, LEFRANC and piezocone dissipation test). The measurements, taken from 155 locations, show a high spatial variability, with ranges spanning more than two orders of magnitude. The results also reveal that the estimated permeabilities vary significantly among methods. These discrepancies reflect the scale dependency of the hydraulic conductivity in the area caused by soil heterogeneities. A comparison of the presented results with previous studies demonstrates that piezocone tests provide representative results for the clayey formations, while LEFRANC tests better estimate the hydraulic conductivity of the permeable strata. Besides, CPTu tests yield more consistent values of hydraulic conductivity, with smaller dispersion than well permeameter and LEFRANC tests.
\end{abstract}

Keywords: Hydraulic conductivity, Lake Texcoco, LEFRANC test, USBR test, CPTu test, Piezocone

\footnotetext{
*Corresponding Author: Norma Patricia López-Acosta: Universidad Nacional Autónoma de México Mexico City, Coyoacán Mexico, E-mail: nlopeza@iingen.unam.mx Alejandra Liliana Espinosa-Santiago, David Francisco BarbaGaldámez: Universidad Nacional Autónoma de México
}

\section{Introduction}

The construction of the New Mexico International Airport (NAIM) has drawn renewed attention to the subsoil conditions of the former Lake Texcoco. This area overlies a series of soft clay and clayey silts, widely known for their high water content and large compressibility, interlayered by units of cemented clastic material [1]. In the past, several authors have studied the mechanical characteristics of the clayey deposits [1-6]. However little research has been conducted to evaluate their hydraulic properties. In particular, the available information about the permeability of the deeper strata is scarce.

A comprehensive hydraulic characterization of the area is important for the design of airport and hydraulic structures under construction. Hydraulic conductivity $k$ affects geotechnical analyses that involve water flow within the ground or earth structures, such as uplift pressure in excavations, regional subsidence and the effects of rain infiltrations on slope stability of lagoons and canals. It also exerts a strong influence on the design of pumping systems and soft ground improvement methods. Despite its great importance, the accurate evaluation of this parameter remains a complex task because of soil's inherent heterogeneity. Many authors have documented the great spatial variability of $k$, finding coefficients of variation up to several orders of magnitude [7-9]. Furthermore, soil permeability can vary with the measurement scale. Some field features (e.g., fractures, cracks and pervious seams) create preferred flow paths that increase the value of $k$ as the volume of tested material augments [10].

The methods to determine soil hydraulic properties include laboratory and in-situ tests. Although the former are economical, relatively quick and allow controlling different boundary conditions, they require an appropriate sample handling and provide just local $k$ values. In-situ methods, instead, evaluate a more representative volume of soil under actual field conditions. However, most of them are costly, laborious and time-consuming. These drawbacks complicate the obtainment of large datasets required for studying the spatial variability of the hydraulic conductiv- 
ity. As an alternative, soil permeability can be estimated indirectly from direct-push probings carried out to determine other geotechnical properties (e.g., piezocone and flat dilatometer tests). The simplicity, inexpensiveness and speed of these indirect in-situ methods enable the acquisition of a greater number of measurements. Nevertheless, most of the proposed interpretation theories are empirical and their applicability is restricted to specific soil types and field conditions.

This paper presents a systematic evaluation of soil permeability in the former Lake Texcoco through three different in-situ methods: well permeameter, LEFRANC and piezocone dissipation test. The characterization provides the permeability values of previously unexplored strata and applies univariate statistics to evaluate the influence of the various measurement techniques. Accordingly, the specific objectives of this study are: (a) to determine the hydraulic conductivity of clayey and permeable strata of the former Lake Texcoco using different in-situ methods; (b) to evaluate the ability of indirect in-situ methods to estimate accurate and reliable values of $k$; and (c) to quantify the scale effects in the determination of soil permeability in the study zone.

\section{Methods}

\subsection{Geological and geotechnical context of the study area}

The study area (bounded by latitude $19^{\circ} 28^{\prime} 12^{\prime \prime}-19^{\circ} 33^{\prime} 36^{\prime \prime}$ N and longitude $98^{\circ} 56^{\prime} 24^{\prime \prime}-99^{\circ} 01^{\prime} 12^{\prime \prime} \mathrm{W}$ ) lies at the lowest portion of the Basin of Mexico, formerly occupied by Lake Texcoco (State of Mexico, Mexico). The Basin of Mexico is a compound graben of $9600 \mathrm{~km}^{2}$ elongated in the NNESSW direction (about $125-\mathrm{km}$ length and $75-\mathrm{km}$ width). It is bounded on the north by the Pachuca Range, east by the Río Frío and the Nevadas Ranges, south by Chichinautzin Range and west by the Ajusco Volcano and Las Cruces Range [11]. The basin is an extensive plain with an average elevation of $2240 \mathrm{~m}$ above sea level and a subtropical climate [12]. It was originally open until 700,000 years ago when volcanic activity blocked its drainage resulting in the development of an extensive system of lakes: Zumpango, Xaltocan, Texcoco, Xochimilco and Chalco. During this period, lacustrine sediments, volcanic ash and other pyroclastic materials were deposited overlaying previous alluvial-fluvial sediments [13]. The basin remained closed until the completion of the Nochistongo cut in 1789. The construction of new drainage systems and land reclamation for urban expansion during the 20th century caused the gradual shrinking of the lakes, which today have practically disappeared [14]. Fig. 1 shows a geologic map of the Basin of Mexico.

The site stratigraphy corresponds to a typical Lacustrine Zone according to Mexico City Geotechnical Zoning [16]. Soil strata consist of soft clays and clayey silts interspersed with seams and layers of harder clayey silts with sands. As seen in Table 1, the soil strata are: a) Surface Crust (SC) of light brown fat clay of soft consistency with the presence of cracks; b) Upper Clay Formation (UCF), a thick layer of very soft lacustrine clay interspersed with relatively thin seams of volcanic origin and sandy silt; c) Hard Layer (HL) composed of thin layers of hard sandy silt with variable cementation; d) Lower Clay Formation (LCF), a green brown clay interspersed with gray fat clay of the same origin of the UCF; e) Deep Deposits (DD) formed by silts and sand interspersed with hard clays; f) Deep Clay Formation (DCF), a soft to very firm clay layer with similar characteristics to the others; and g) Deep Stratified Formation (DSF) composed of stratified deposits of clay, sand and silty sand.

The thickness of the strata remains relatively constant, with exception of the UCF that increases from northeast to southwest (Table 1). Clayey formations are characterized by their extremely high water content (varying from 300 to $400 \%$, but in some areas of the UCF values of up to $600 \%$ have been registered) and void ratios (between 24 in the DCF, 3-6 in the LCF and above 6 in the UCF), high plasticity index and extraordinary compressibility $[1,2,4]$. Anisotropy is an important factor in Texcoco's soils due to the presence of permeable seams and their intrinsic geological formation process. Generally, clays have greater horizontal permeability $k_{h}$ than vertical permeability $k_{v}$, with ratios of $k_{h} / k_{v}$ ranging from 1.1 to 10.0 [17-23]. Field or laboratory estimates of the anisotropy of the former Lake Texcoco clays have not been obtained yet, however, considering their layering, a value of $k_{h} / k_{v}$ between 2 and 5 may be assumed $[4,18,20]$.

The groundwater table is close to the surface. Previous pumping wells for brine extraction have caused a significant depletion of the hydrostatic pressure influencing the stress condition at the site (Fig. 2). In-situ piezometric measurements show that the drawdown is gradual in the study area, beginning at a lower depth in the north (between 5 and $10 \mathrm{~m}$ ) and deepening to the south (between 20 and $24 \mathrm{~m}$ ). In addition, the subsoil of the site has a high salt content, even the presence of gas has been detected (mainly methane). 

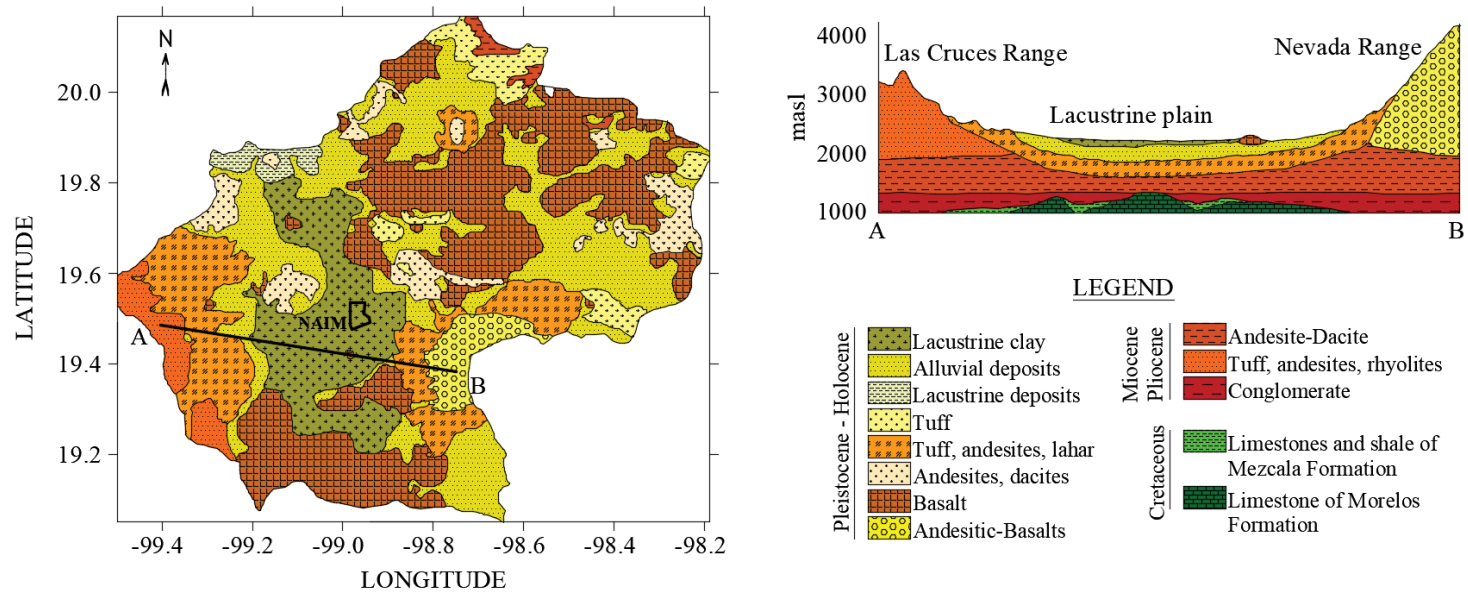

Figure 1: Geologic map of the Basin of Mexico (adapted from [15]).

Table 1: Stratigraphic description of the study site.

\begin{tabular}{lllll}
\hline Stratum & ID & $\begin{array}{l}\text { USCS } \\
\text { Classification }\end{array}$ & Thickness $(\mathbf{m})$ & $\begin{array}{l}\text { Unit weight, } \gamma \\
\left(\mathbf{k N} / \mathbf{m}^{3}\right)\end{array}$ \\
\hline Surface Crust & SC & CH & $0-1.6$ & 15 \\
Upper Clay Formation & UCF & CH & $18-35$ & 12 \\
Hard Layer & HL & ML & $2-3$ & 16 \\
Lower Clay Formation & LCF & CH & $5-12$ & 13 \\
Deep Deposits & DD & - & $8-10$ & 18 \\
Deep Clay Formation & DCF & CH & $9-11$ & 15 \\
Deep Stratified Formation & DSF & - & $16-19$ & 17 \\
\hline
\end{tabular}

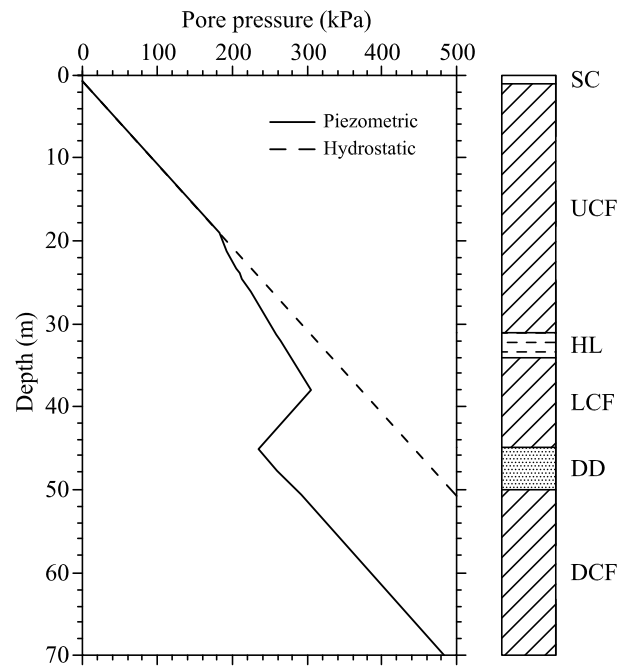

a)

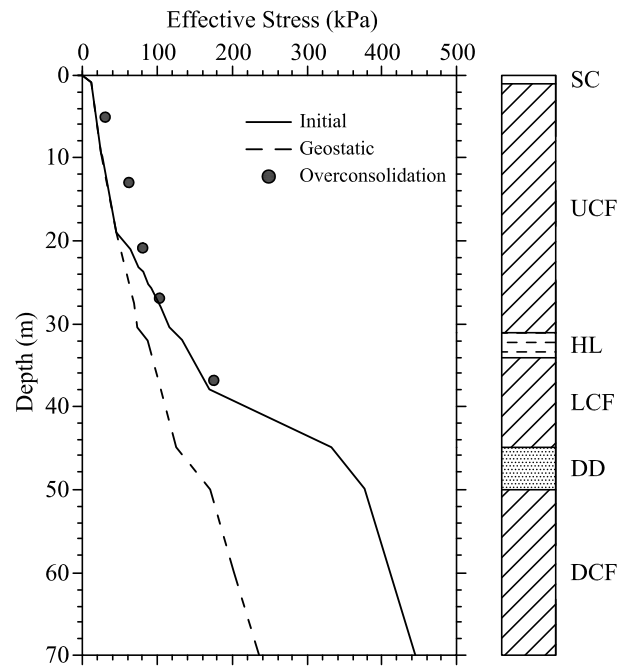

b)

Figure 2: Initial stress conditions at the study site: a) pore pressure, b) effective stress.

\subsection{Previous studies of hydraulic conductivity}

Most prior research at the former Texcoco Lake has focused on evaluating the hydraulic conductivity of the uppermost 
strata, i.e. up to the DD. In 1974, [24] proposed a mathematical model to predict the settlement that would occur in the construction of four artificial lakes for the Lake Texcoco project. The authors estimated the permeability of the UCF and LCF from consolidation tests, whereas they obtained the permeability of the HL and DD from field pumping tests performed in the area between 1967 and 1968. In 1989, [13] investigated the hydraulic behavior of the Texcoco saline aquifer system by evaluating historical data, field studies, and numerical analyses of underground flow and solute transport. For the hydrogeological model, they determined the permeabilities of the HL and DD from a series of pumping tests and the hydraulic conductivity of the UCF and LCF from standard consolidation tests performed by $[1,2]$. More recently, [4] estimated the horizontal hydraulic conductivity of the UCF and LCF from excess pore pressure dissipation records of a piezocone test (CPTu) done in 2000, while [25] performed a series of flexible wall permeameter tests. Table 2 presents a summary of hydraulic conductivities determined in the area according to the aforementioned studies.

\subsection{Current measurement of saturated hydraulic conductivity $k$ of soils}

Three different in-situ measuring techniques were used to estimate the hydraulic conductivity in the study area: Well Permeameter Method (USBR 7300-89), LEFRANC (NF P94132) and Piezocone ( $\mathrm{CPTu}$ ) test. The test campaign was part of the geotechnical survey performed for the construction of the New Mexico International Airport (NAIM) and included for the first time an extended study of the lower formations (DCF and DSF). Fig. 3 provides information about the location of the 155 test completed (21 USBR, 15 LEFRANC and $119 \mathrm{CPTu}$ ), including a location map of the study site.

\subsubsection{Well Permeameter Method (USBR 7300-89)}

The well permeameter method, also known as USBR test, is an in-situ test originally developed for assessing the hydraulic conductivity of semipervious and pervious soils $\left(k \geq 1 \times 10^{-7} \mathrm{~m} / \mathrm{s}\right)$ along canal alignments and reservoir sites [26]. In general, it consists of injecting water into an uncased well and measuring the flow rate under a constant gravity head (Fig. 4a). Data analysis depends on the location of the groundwater table and impervious soil layers. For high groundwater tables, the hydraulic conductivity $k$ can be estimated as:

$$
k=\frac{q V}{2 \pi h^{2}}\left[\frac{\ln (h / r)}{\left(h / T_{u}\right)^{-1}+\frac{1}{2}\left(h / T_{u}\right)^{-2}}\right]
$$

where $h$ is the height of water in the well, $r$ is the radius of the well, $q$ is the discharge rate under steady-state condition, $V$ is the ratio of water viscosity at the temperature of the test to water viscosity at $20{ }^{\circ} \mathrm{C}$, and $T_{u}$ the unsaturated distance between the water surface in the well and the groundwater table.

\subsubsection{LEFRANC test}

The LEFRANC test is a variable-head method developed to estimate the hydraulic conductivity of coarse and fine soils located below the groundwater table. The test consists of injecting water by gravity into a cavity of known dimensions and measuring the subsequent water level decline over time (Fig. 4b) [27]. Percolation takes place through an infiltration chamber (usually $1 \mathrm{~m}$ long) filled with clean gravel located at the bottom of a casing. By evaluating the mass-balance equilibrium, the hydraulic conductivity $k$ can be calculated as:

$$
k=A_{i} C \frac{\ln \left(\frac{h_{1}}{h_{2}}\right)}{t_{2}-t_{1}}
$$

where $A_{i}$ is the internal cross-section of the borehole, $h_{1}$ and $h_{2}$ are the differences in the total head at times $t_{1}$ and $t_{2}$, and $C$ is a shape factor that depends on the ratio of the injection chamber length $L$ to its diameter $D$. For ratios between 1.2 and 10, [28] suggests using the ellipsoid formula:

$$
C=\frac{2 \pi\left(\frac{L}{D}\right)}{\ln \left(\frac{L}{D}+\sqrt{\left(\frac{L}{D}\right)^{2}+1}\right)}
$$

\subsubsection{Piezocone dissipation test (CPTu)}

In the piezocone (CPTu) test an instrumented steel probe is driven into the ground at a constant speed $(2 \mathrm{~cm} / \mathrm{s})$ to obtain a continuous record of tip resistance, sleeve friction and pore water pressure induced during cone penetration (Fig. 4c). These measurements provide valuable information for soil profiling and estimation of its mechanical and hydraulic properties [29]. As an alternative to continuous penetration, the dissipation of the interstitial water pressure at a certain depth can be studied [4]. A dissipation test involves interrupting the steady penetration of the cone and measuring over time the decay of induced excess pore 
Table 2: Summary of permeabilities previously estimated in the former Lake Texcoco.

\begin{tabular}{|c|c|c|c|c|}
\hline \multirow[b]{2}{*}{$\begin{array}{c}\text { Soil } \\
\text { stratum }\end{array}$} & \multicolumn{4}{|c|}{ Hydraulic conductivity, $k(\mathrm{~m} / \mathrm{s})$} \\
\hline & $\begin{array}{l}\text { Herrera et al. } \\
\text { (1974) [24] }\end{array}$ & $\begin{array}{l}\text { Rudolph et al. } \\
\text { (1989) [13] }\end{array}$ & $\begin{array}{l}\text { Alanís-González } \\
(2003) \star[4]\end{array}$ & $\begin{array}{l}\text { Lucero-Rivera } \\
\text { (2018) [25] }\end{array}$ \\
\hline $\mathrm{SC}$ & - & - & - & $1.31 \times 10^{-08}$ \\
\hline UCF & $5.44 \times 10^{-09}$ & $5.00 \times 10^{-09}$ & $2.13 \times 10^{-09}$ & $1.61 \times 10^{-09}$ \\
\hline $\mathrm{HL}$ & $9.26 \times 10^{-05}$ & $8.00 \times 10^{-05}$ & - & - \\
\hline LCF & $1.67 \times 10^{-10}$ & $5.00 \times 10^{-09}$ & $4.39 \times 10^{-10}$ & $6.98 \times 10^{-10}$ \\
\hline $\mathrm{DD}$ & $8.68 \times 10^{-05}$ & $1.00 \times 10^{-04}$ & - & $5.58 \times 10^{-10}$ \\
\hline DCF & - & - & - & $4.46 \times 10^{-09}$ \\
\hline
\end{tabular}

Note: SC = Surface Crust; UCF = Upper Clay Formation; HL = Hard Layer; LCF = Lower Clay Formation; DD = Deep Deposits; and DCF = Deep Clay Formation. ${ }^{\star}$ Value of horizontal hydraulic conductivity.

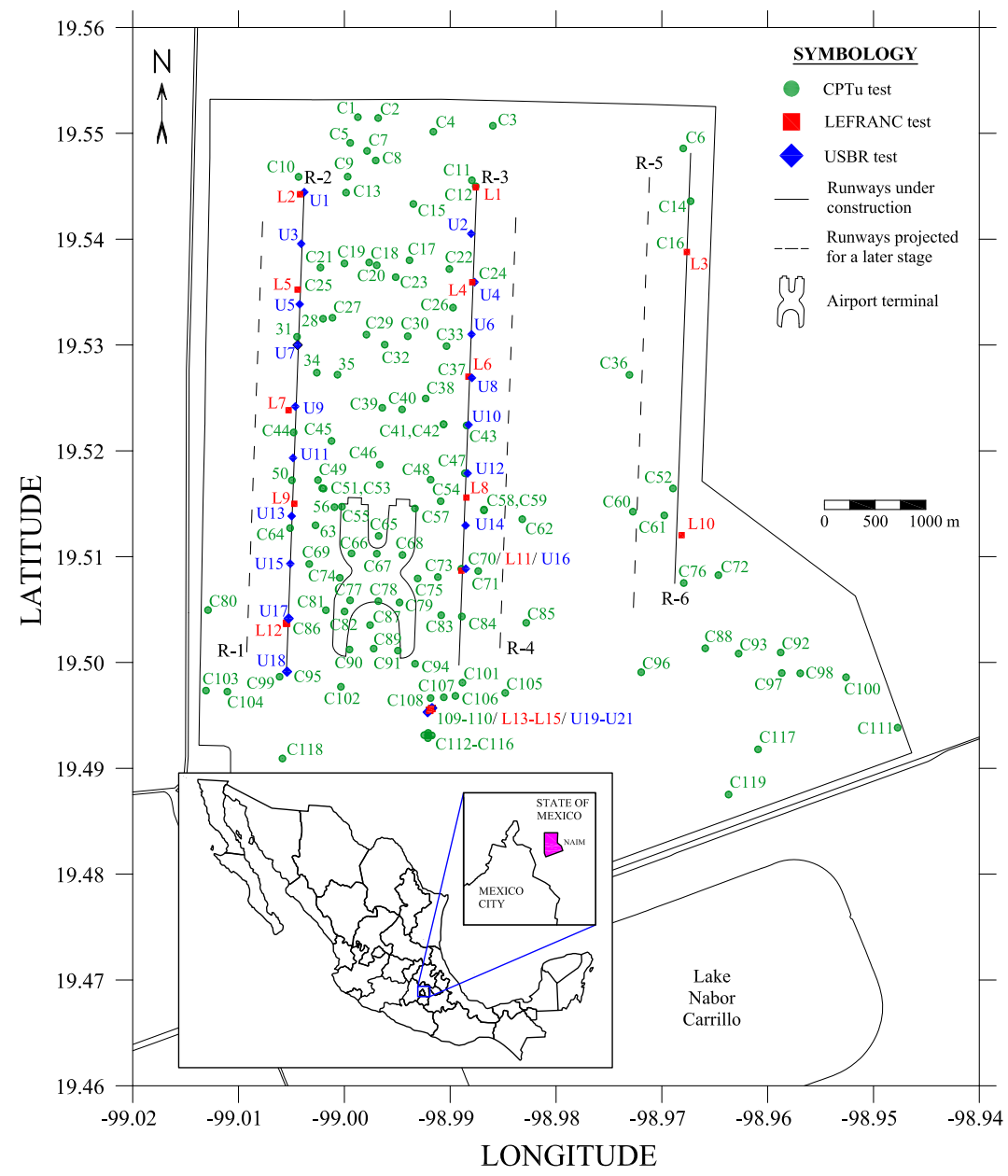

Figure 3: Overview of the study area and location of the field tests.

Note: R-\# = Runway; C\# = CPTu test; L\# = LEFRANC test; U\# = USBR test. 
water pressure until reaching the equilibrium pressure or some percentage of it. Fig. 5 presents typical dissipation records for different clayey formations of the former Lake Texcoco.

The dissipation process is mainly radial, and it is controlled by the horizontal coefficient of consolidation $C_{h}$, which in turn is a function of the soil horizontal permeability $k_{h}$ [30]. There are many methods to estimate the value of $k_{h}$ using dissipation test data [18, 31-34]. The selection of a specific interpretation theory depends on the amount of information available about the equipment, stratigraphy and initial stress conditions at the site. [35] studied the applicability of four different methods in the former Lake Texcoco and concluded that both the [18] and [34] proposals provide sufficiently representative results of the soil strata. Accordingly, the theory of [18] was chosen for the present article.

The solution proposed by [18] gives a rational interpretation method based on linear uncoupled consolidation analyses (i.e., $C_{h}$ does not change during consolidation). It assumes that the soil behaves as a homogeneous, isotropic, linear-elastic material. Thus, $C_{h}$ can be calculated as:

$$
C_{h}=\frac{R^{2} T_{X}}{t_{x}}
$$

where $R$ is the radius of the cone shaft, $t_{x}$ is the measured time to reach a degree of consolidation $x$ and $T_{X}$ is its corresponding time factor.

Eq. (4) implicitly considers that the dissipation is mainly controlled by the soil properties within a cylindrical cavity of radius $R$, though the failure zone caused by cone penetration extends a distance at least four to six times $R$ [36]. In linear analysis, $C_{h}$ is proportional to the ratio of permeability to compressibility, therefore [18] proposed the following equation to determine $k_{h}$ :

$$
k_{h}=\frac{\gamma_{w}}{2.3 p_{v o}^{\prime}} \bullet R R \bullet C_{h}
$$

where $p^{\prime}{ }_{v o}$ is the initial vertical effective stress, $\gamma_{w}$ is the unit weight of water, $R R$ is the recompression ratio controlling dissipation around the piezocone.

It is important to note that the piezocone provides only parameters in the horizontal direction. Parameters in the vertical direction can be estimated from empirical correlations that consider the anisotropy and stratification of soils, as discussed in Section 2.1.

\section{Results}

The hypothesis of linear consolidation is not valid for all soils. According to [30], linear solutions are reasonably applicable to normally consolidated clays, however [18] recommends checking the validity of this assumption when dissipation tests are first conducted at a new site. For this, they suggest calculating $C_{h}$ with Eq. (4) at different degrees of consolidation. Large discrepancies between the estimated values of $C_{h}$ indicate that coupling effects are significant and this methodology is not applicable. Table 3 shows the horizontal coefficient of consolidation $C_{h}$ and hydraulic conductivity $k_{h}$ calculated at different degrees of consolidation for the dissipation data of the study site presented in Fig. 5. Discussion of results is given in Section 4.

Table 4 presents summary statistics of the hydraulic conductivity $k$ for each in-situ test. Several authors have suggested that the variability of the hydraulic conductivity can be described using the lognormal distribution [37-42], thus Table 4 includes the geometric mean and the standard deviation of the decimal logarithms of $k$ as a more reliable measure of central tendency and dispersion of the dataset, respectively.

\section{Discussion}

\subsection{Applicability of piezocone dissipation test (CPTu) to estimate hydraulic conductivity in the former Lake Texcoco}

The values presented in Table 3 show that $C_{h}$ remains approximately constant during the consolidation process for the different clayey strata. Furthermore, the maximum difference between $k_{h}$ estimated with Eq. (5) is less than half order of magnitude. As stated in Section 2.1, anisotropy is an important factor of Texcoco's clays, therefore a direct comparison of the estimated hydraulic conductivity with CPTu and previous studies $[4,13,24,25]$ is not possible. Assuming a ratio $k_{h} / k_{v}=3[4,18,20]$, the geometric means of $k_{v}$ of the UCF, LCF, DCF and DSF are $1.29 \times 10^{-9}, 1.61 \times 10^{-9}$, $7.86 \times 10^{-10}$ and $9.75 \times 10^{-10} \mathrm{~m} / \mathrm{s}$, respectively. These values are similar to those reported in Table 4 and show that the selected interpretation method provide representative results for the clayey formations in the former Lake Texcoco. This confirms the applicability of linear uncoupled consolidation theory for the analysis of dissipation curves and suggests that indirect in-situ methods, such as CPTu, con- 


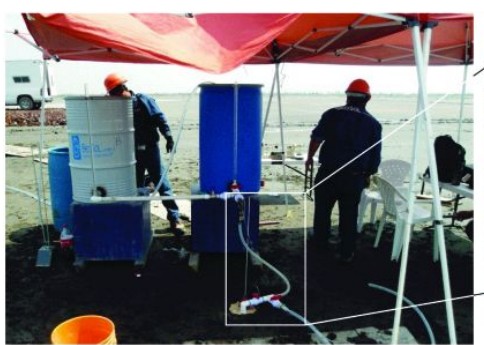

a)

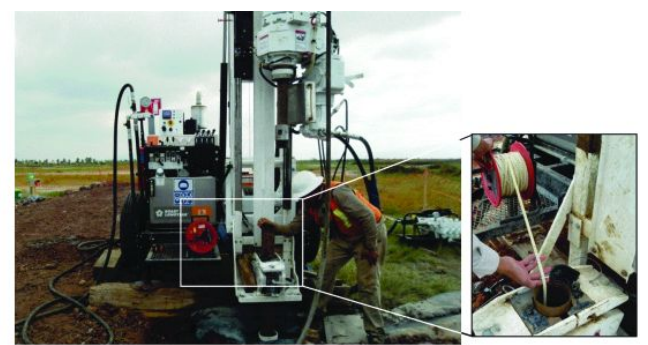

b)

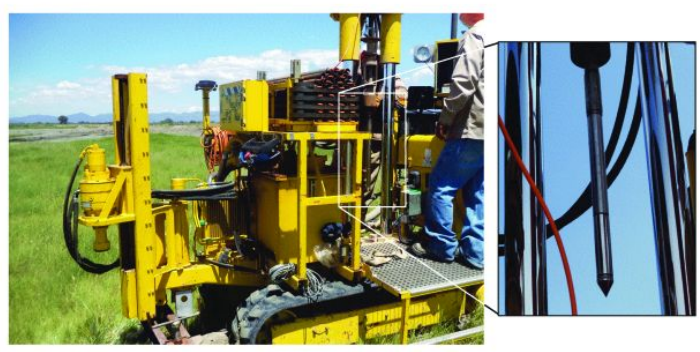

c)

Figure 4: In-situ tests: a) Well permeameter (USBR), b) LEFRANC, c) Piezocone dissipation test (CPTu) (photos courtesy of Federal Electricity Commission and GEOSOL).

Table 3: Horizontal coefficient of consolidation $C_{h}$ and hydraulic conductivity $k_{h}$ calculated at different degrees of consolidation.

\begin{tabular}{|c|c|c|c|c|c|c|c|c|}
\hline \multirow{2}{*}{$\begin{array}{l}\text { Depth } \\
\text { (m) }\end{array}$} & \multirow{2}{*}{$\begin{array}{c}\text { Soil } \\
\text { stratum }\end{array}$} & \multirow[t]{2}{*}{ Parameter } & \multirow[t]{2}{*}{ Unit } & \multicolumn{5}{|c|}{ Degree of consolidation ( $\%)$} \\
\hline & & & & 30 & 40 & 50 & 60 & 70 \\
\hline \multirow{2}{*}{24.38} & \multirow{2}{*}{ UCF } & $C_{h}$ & $\mathrm{~m}^{2} / \mathrm{s}$ & $1.74 \times 10^{-05}$ & $2.19 \times 10^{-05}$ & $2.51 \times 10^{-05}$ & $2.88 \times 10^{-05}$ & $3.15 \times 10^{-05}$ \\
\hline & & $k_{h}$ & $\mathrm{~m} / \mathrm{s}$ & $5.46 \times 10^{-09}$ & $6.88 \times 10^{-09}$ & $7.89 \times 10^{-09}$ & $9.07 \times 10^{-09}$ & $9.91 \times 10^{-09}$ \\
\hline \multirow{2}{*}{29.73} & \multirow{2}{*}{ LCF } & $C_{h}$ & $\mathrm{~m}^{2} / \mathrm{s}$ & $8.00 \times 10^{-05}$ & $8.26 \times 10^{-05}$ & $8.94 \times 10^{-05}$ & $8.49 \times 10^{-05}$ & $9.35 \times 10^{-05}$ \\
\hline & & $k_{h}$ & $\mathrm{~m} / \mathrm{s}$ & $1.59 \times 10^{-08}$ & $1.64 \times 10^{-08}$ & $1.78 \times 10^{-08}$ & $1.69 \times 10^{-08}$ & $1.86 \times 10^{-08}$ \\
\hline \multirow{2}{*}{45.3} & \multirow{2}{*}{ DCF } & $C_{h}$ & $\mathrm{~m}^{2} / \mathrm{s}$ & $6.12 \times 10^{-06}$ & $6.74 \times 10^{-06}$ & $7.91 \times 10^{-06}$ & $8.69 \times 10^{-06}$ & $1.02 \times 10^{-05}$ \\
\hline & & $k_{h}$ & $\mathrm{~m} / \mathrm{s}$ & $6.83 \times 10^{-10}$ & $7.52 \times 10^{-10}$ & $8.84 \times 10^{-10}$ & $9.71 \times 10^{-10}$ & $1.13 \times 10^{-09}$ \\
\hline \multirow{2}{*}{50.06} & \multirow{2}{*}{ DCF } & $C_{h}$ & $\mathrm{~m}^{2} / \mathrm{s}$ & $2.49 \times 10^{-05}$ & $2.74 \times 10^{-05}$ & $2.79 \times 10^{-05}$ & $3.11 \times 10^{-05}$ & $3.53 \times 10^{-05}$ \\
\hline & & $k_{h}$ & $\mathrm{~m} / \mathrm{s}$ & $2.56 \times 10^{-09}$ & $2.82 \times 10^{-09}$ & $2.87 \times 10^{-09}$ & $3.20 \times 10^{-09}$ & $3.63 \times 10^{-09}$ \\
\hline \multirow{2}{*}{67.59} & \multirow{2}{*}{ DSF } & $c_{h}$ & $\mathrm{~m}^{2} / \mathrm{s}$ & $1.33 \times 10^{-05}$ & $1.74 \times 10^{-05}$ & $2.08 \times 10^{-05}$ & $2.41 \times 10^{-05}$ & $2.95 \times 10^{-05}$ \\
\hline & & $k_{h}$ & $\mathrm{~m} / \mathrm{s}$ & $8.16 \times 10^{-10}$ & $1.07 \times 10^{-09}$ & $1.28 \times 10^{-09}$ & $1.48 \times 10^{-09}$ & $1.82 \times 10^{-09}$ \\
\hline
\end{tabular}

Note: UCF = Upper Clay Formation; LCF = Lower Clay Formation; DCF = Deep Clay Formation; and DSF = Deep Stratified Formation.

stitute a valid alternative to traditional field tests for determining $k$ values in the study area. The application of such indirect techniques can help to reduce costs and time, optimizing the geotechnical site characterization process. It should be noted that the values of the estimated $k_{v}$ are practically in the same order of magnitude of $k_{h}$. However, a comprehensive study of the in-situ anisotropy of Texcoco clayey formations is still necessary to provide reliable estimates of the vertical hydraulic conductivity.

\subsection{Influence of the measurement technique}

The results presented in Table 4 also suggest that the estimated hydraulic conductivity vary significantly among methods. The different locations of the tests hinder a pointto-point comparison of the measurement techniques. However, an analysis of the global summary statistics shows that both the USBR and the LEFRANC tests provide consistently higher permeabilities and exhibit greater dispersion than CPTu. In general, the values estimated with the $\mathrm{CPTu}$ are consistent with those reported in the literature for the clayey formations (UCF, LCF and DCF) (Table 4), but lower for the DD. Conversely, LEFRANC tests 
Table 4: Summary of hydraulic conductivity statistics currently estimated in the former Lake Texcoco.

\begin{tabular}{|c|c|c|c|c|c|c|c|}
\hline \multirow{2}{*}{ Test } & & \multicolumn{2}{|c|}{ Soil stratum } & \multirow[b]{2}{*}{ LCF } & \multirow[b]{2}{*}{ DD } & \multirow[b]{2}{*}{ DCF } & \multirow[b]{2}{*}{ DSF } \\
\hline & & UCF & HL & & & & \\
\hline \multirow{5}{*}{ USBR } & $n$ & 40 & - & - & - & - & - \\
\hline & $\operatorname{Min}(m / s)$ & $4.60 \times 10^{-06}$ & - & - & - & - & - \\
\hline & $\operatorname{Max}(\mathrm{m} / \mathrm{s})$ & $1.14 \times 10^{-04}$ & - & - & - & - & - \\
\hline & $m_{k}(\mathrm{~m} / \mathrm{s})$ & $2.08 \times 10^{-06}$ & - & - & - & - & - \\
\hline & $\boldsymbol{s}_{k}$ & 1.18 & - & - & - & - & - \\
\hline \multirow{5}{*}{ LEFRANC } & $n$ & 6 & 12 & - & 14 & - & 13 \\
\hline & $\operatorname{Min}(m / s)$ & $1.07 \times 10^{-09}$ & $8.46 \times 10^{-07}$ & - & $8.38 \times 10^{-10}$ & - & $5.42 \times 10^{-06}$ \\
\hline & $\operatorname{Max}(\mathrm{m} / \mathrm{s})$ & $2.55 \times 10^{-08}$ & $3.51 \times 10^{-04}$ & - & $6.95 \times 10^{-04}$ & - & $1.41 \times 10^{-03}$ \\
\hline & $m_{k}(\mathrm{~m} / \mathrm{s})$ & $6.69 \times 10^{-09}$ & $2.39 \times 10^{-05}$ & - & $5.57 \times 10^{-06}$ & - & $9.11 \times 10^{-05}$ \\
\hline & $s_{k}$ & 0.46 & 0.88 & - & 1.84 & - & 0.76 \\
\hline \multirow{5}{*}{ CPTu* } & $n$ & 46 & - & 30 & 57 & 46 & 50 \\
\hline & $\operatorname{Min}(m / s)$ & $4.21 \times 10^{-10}$ & - & $5.60 \times 10^{-10}$ & $5.84 \times 10^{-10}$ & $4.32 \times 10^{-10}$ & $2.43 \times 10^{-10}$ \\
\hline & $\operatorname{Max}(m / s)$ & $2.40 \times 10^{-08}$ & - & $3.42 \times 10^{-08}$ & $3.41 \times 10^{-08}$ & $8.18 \times 10^{-09}$ & $4.17 \times 10^{-08}$ \\
\hline & $m_{k}(\mathrm{~m} / \mathrm{s})$ & $3.88 \times 10^{-09}$ & - & $4.84 \times 10^{-09}$ & $5.19 \times 10^{-09}$ & $2.36 \times 10^{-09}$ & $2.93 \times 10^{-09}$ \\
\hline & $\boldsymbol{s}_{k}$ & 0.36 & - & 0.41 & 0.48 & 0.32 & 0.49 \\
\hline
\end{tabular}

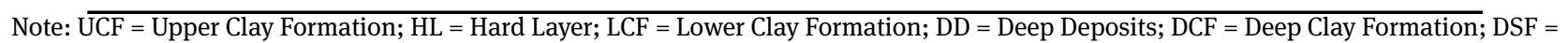
Deep Stratified Formation; $\mathrm{n}=$ sample size; Min = minimum; Max = maximum; $m_{k}=$ geometric mean of $k ; s_{k}=$ standard deviation of log $(k)$. *Value of horizontal hydraulic conductivity.

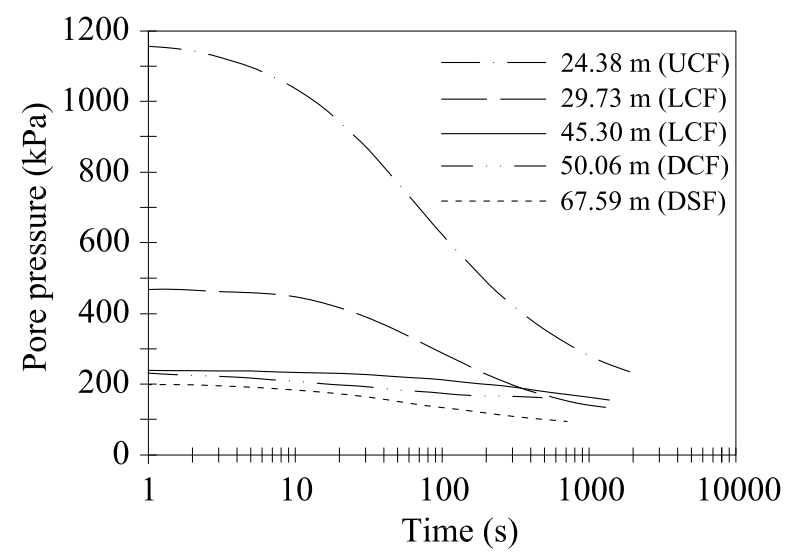

Figure 5: Pore pressure dissipation curves of the CPTu tests at different depths in the study site.

provide similar results to those reported for the more permeable and heterogeneous strata (HL and DD). Fig. 6 contrasts the distribution of the estimated $k$ values in three strata (UCF, DD and DSF) and shows that this difference can be as many as four orders of magnitude.

Several authors have reported similar behaviors, which have been attributed to differences in flow geometry, measurement scales and inherent disturbances during testing [10, 42-45]. Although an exhaustive analysis of the causes of these discrepancies is beyond the scope of the present article, scale effects are likely the most signif- icant factors. Compared to CPTu, USBR and LEFRANC affect a larger volume of soil, which increases the influence of material heterogeneity. Fractures, cracks and pervious seams in the soil matrix create preferred pathways that allow faster flow and increase the measured value of $k$ [10]. The presence of preferred flow paths explain the higher hydraulic conductivities estimated with the USBR test. These measurements were performed at shallow depths of the UCF (Fig. 7) which are characterized by the existence of extensive fracture networks [13]. Scale effects may also clarify the discrepancies obtained in the hydraulic conductivity of the DD and the DSF. Pumping tests used by $[13,24]$ have a large area of influence, slightly greater than the evaluated with the LEFRANC test. By contrast, CPTu and flexible well permeameter tests evaluate a considerably lower volume of soil, which limits the effects of the strata heterogeneities. Consequently, the permeabilities reported by the former authors are almost four orders of magnitude higher.

\subsection{Spatial variability of the hydraulic conductivity}

Fig. 7 evidences the variability of the hydraulic conductivity across the study area. The $k$ values span more than two orders of magnitude regardless of the stratum or the mea- 


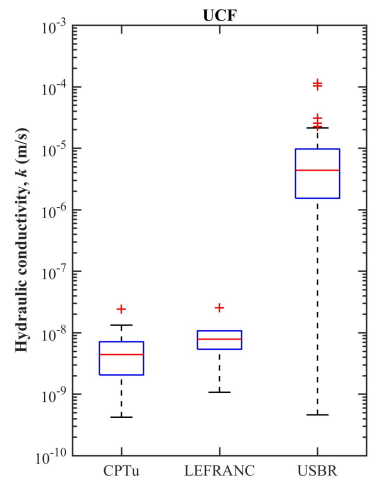

a)

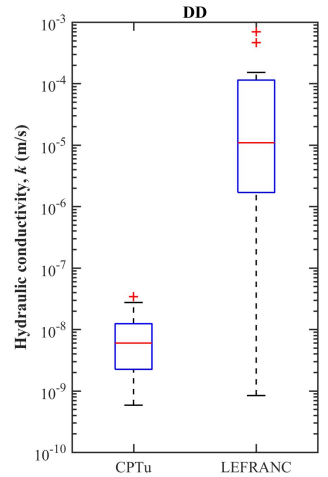

b)

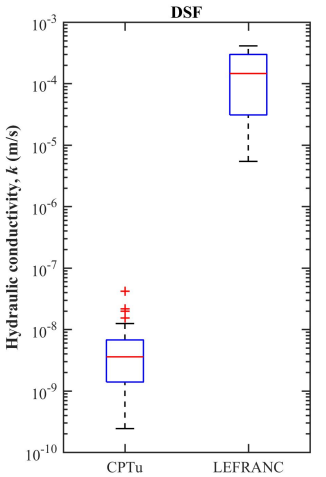

c)

Figure 6: Boxplot comparison of hydraulic conductivity obtained using CPTu, LEFRANC and USBR methods: a) UCF, b) DD, c) DSF.
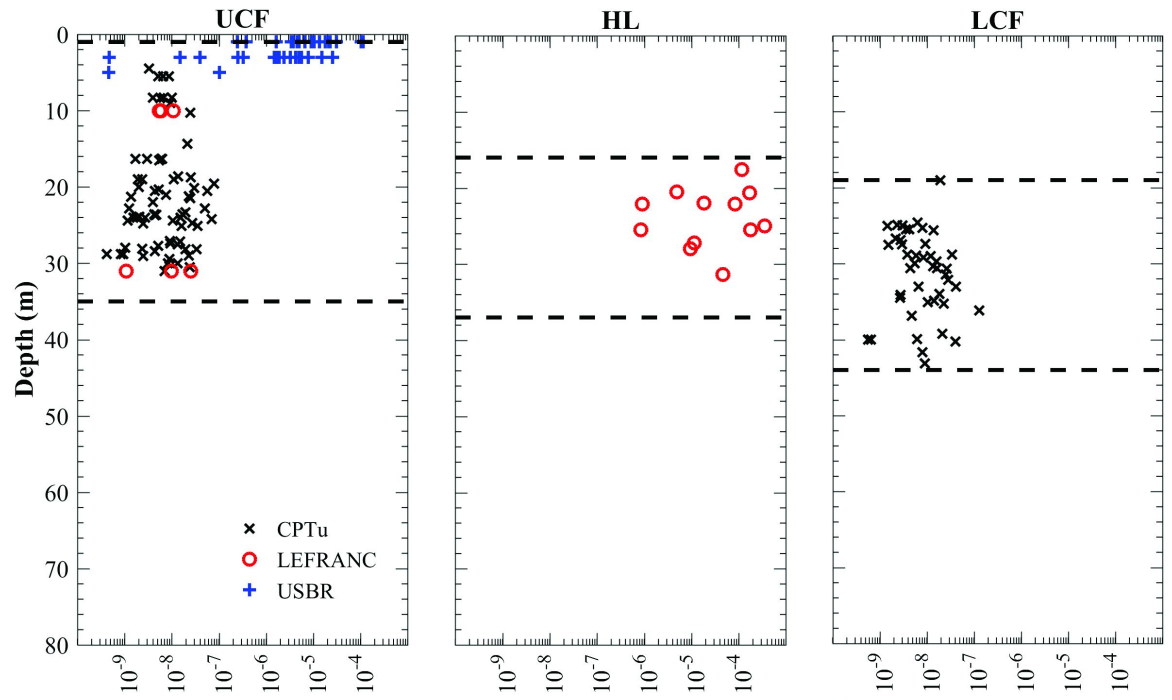

Hydraulic conductivity, $k(\mathrm{~m} / \mathrm{s})$

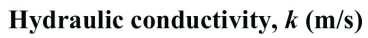

Hydraulic conductivity, $k(\mathrm{~m} / \mathrm{s})$
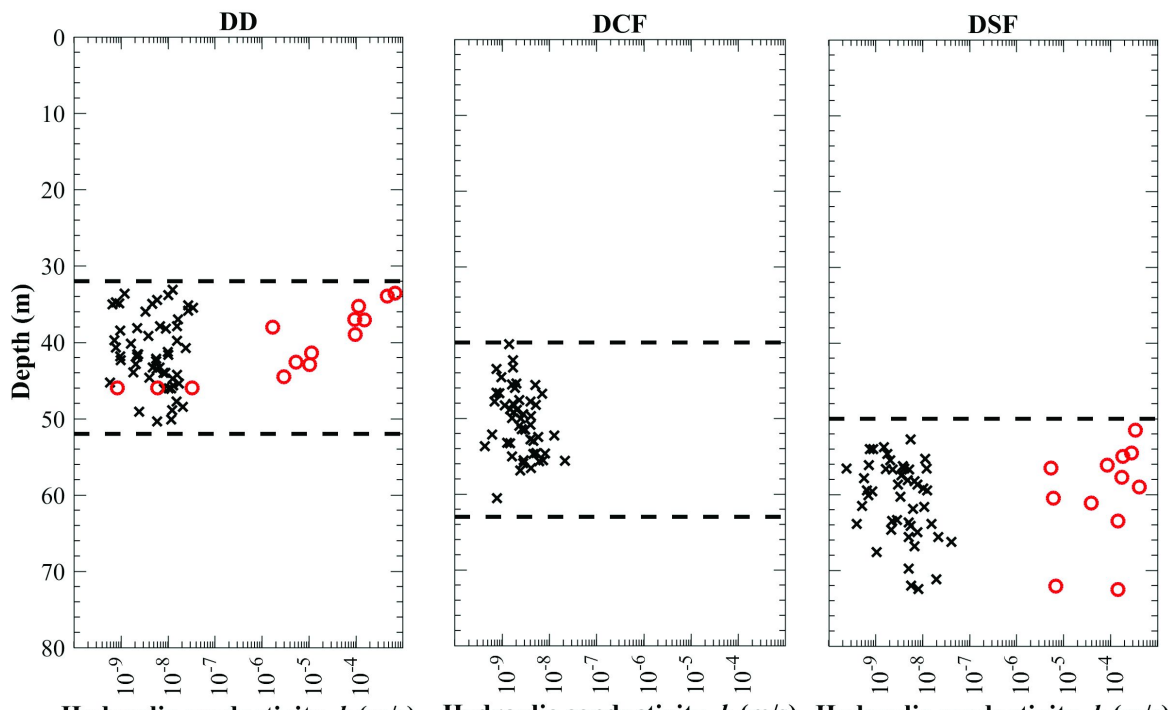

Hydraulic conductivity, $k(\mathrm{~m} / \mathrm{s}) \quad$ Hydraulic conductivity, $k(\mathrm{~m} / \mathrm{s})$ Hydraulic conductivity, $k(\mathrm{~m} / \mathrm{s})$

Figure 7: Profiles of the hydraulic conductivity variability for each stratum. 
surement technique. This variability is typical of natural and compacted soils, which can have a coefficient of variation $C V$ up to $500 \%$ [7-9]. Despite their great dispersion, the data also suggest that all clayey formations (UCF, LCF, DCF and DSF) have similar hydraulic characteristics. According to CPTu results, the horizontal permeabilities of these strata range from $10^{-10}$ to $10^{-8} \mathrm{~m} / \mathrm{s}$ with a standard deviation between 0.3 and 0.5 (Fig. 8).

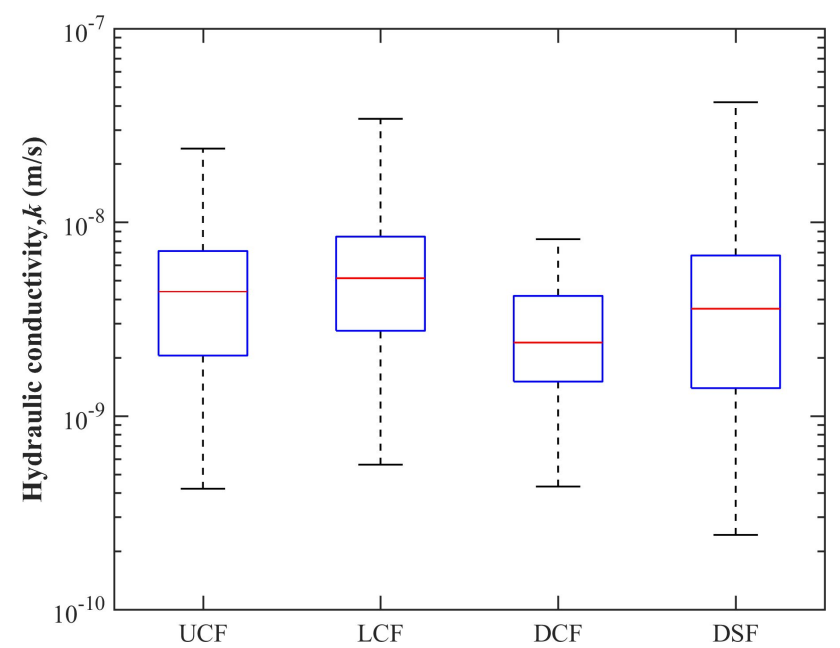

Figure 8: Boxplot comparison of hydraulic conductivity estimated with CPTu test for different clayey formations.

The results show the limitations of traditional univariate statistics to describe the hydraulic conductivity variability in the area. In this context, geostatistical analysis represents a suitable alternative to study the spatial correlation of the sample data and obtain a better characterization of this soil property.

\section{Conclusions}

The hydraulic conductivity is an important parameter for different geotechnical and geohydrological analyses that involve the movement of water within the soil or earth structures. This paper described an extensive geotechnical survey performed to characterize the subsoil hydraulic conductivity $k$ at the former Lake Texcoco. This test campaign was part of the preliminary studies for the construction of the New Mexico International Airport (NAIM) and included for the first time an extended evaluation of unexplored strata (the deepest formations DCF and DSF). The study used three different in-situ methods: well permeameter (USBR), LEFRANC and piezocone dissipation test. The assessment of the results showed that the estimated permeabilities vary significantly among methods with differences up to four orders of magnitude. Piezocone dissipation tests gave consistently lower values of $k$ than the well permeameter (USBR) and LEFRANC methods. CPTu tests yielded more consistent values of the horizontal hydraulic conductivity of the clayey formations, with smaller dispersion than well permeameter and LEFRANC tests, and therefore, they are more reliable. The possible reasons for these discrepancies were mainly related to scale effects. In effect, compared to CPTu, USBR and LEFRANC affect a larger volume of soil, which increases the influence of material heterogeneity. Fractures, cracks and pervious seams in the soil matrix create preferred pathways that increase the measured value and dispersion of $k$. On the other hand, LEFRANC tests provided better estimates of the hydraulic conductivity of the permeable strata. Finally, the results also demonstrated that more work is necessary to assess the great variability of the hydraulic conductivity in the study zone, whose values span more than two orders of magnitude regardless of the stratum or the measurement technique. Further research should focus on implementing geostatistical analyses to investigate its spatial distribution and in the evaluation of in-situ anisotropy.

Acknowledgement: The authors acknowledge the Grupo Aeroportuario de la Ciudad de México for the financial support (GACM-IIUNAM AD-SRO-CONV-DCAGI-SC-13-17) to carry out this research. We also express gratitude to the companies INGEUM, Federal Electricity Commission (CFE) and GEOSOL, who carried out the in-situ tests of this study.

\section{References}

[1] Marsal, R.J., Mazari, M., El subsuelo de la ciudad de México [The subsoil of Mexico City]. Universidad Nacional Autónoma de México, México D.F, 1959 (in Spanish).

[2] Marsal, R.J., Graue, R., El subsuelo del lago de Texcoco [The subsoil of Lake Texcoco]. In: Carrillo, N. (Ed.), El hundimiento de la Ciudad de México y Proyecto Texcoco. Volumen Nabor Carrillo, México D.F., 1969, 167-202 (in Spanish).

[3] Romo, M.P., Auvinet, G., Ovando, E., Mendoza, M.J., Taboada, V.M., Lermo, J.Y. et al., Ingeniería geotécnica para el nuevo aeropuerto internacional de la Ciudad de México: soluciones en el ex Lago de Texcoco y en Zapotlán de Juárez [Geotechnical Engineering in the New Mexico International Airport: solutions in the former Lake Texcoco and in Zapotlán de Juárez]. Informe del Instituto de Ingeniería, UNAM, a Aeropuertos y servicios Auxiliares, 2001 (in Spanish).

[4] Alanís-González, R., Caracterización geotécnica del ex Lago de Texcoco: Ciudad de México [Geotechnical characterization of the former Lake Texcoco: Mexico City]. Masters thesis, Universidad Nacional Autónoma de México, Mexico, 2003 (in Spanish). 
[5] Mayoral, J.M., Romo, M.P., Osorio, L., Seismic parameters characterization at Texcoco lake, Mexico. Soil Dyn. Earthq. Eng., 2008, 28(7), 507-521.

[6] Flores-Guzmán, M., Ovando-Shelley, E., Valle-Molina, C., Smallstrain dynamic characterization of clayey soil from the Texcoco Lake, Mexico. Soil Dyn. Earthq. Eng., 2014, 63, 1-7.

[7] Lumb, P., Application of Statistics in Soil Mechanics. Soil Mechanics: New Horizons, Lee, I. K., ed., London, 1974.

[8] Benson, C.H., Probability Distributions for Hydraulic Conductivity of Compacted Soil Liners. J. Geotech. Geoenviron., 1993, 119(3), 471-486.

[9] Baecher, G.B., Christian, J.T., Reliability and Statistics in Geotechnical Engineering. John Wiley \& Sons, Chichester, 2003.

[10] Schulze-Makuch, D., Carlson, D.A., Cherkauer, D.S., Malik, P., Scale dependency of hydraulic conductivity in heterogeneous media. Ground Water, 1999, 37(6), 904-919.

[11] de Cserna, Z., de la Fuente-Duch, M., Palacios-Nieto, M., Triay, L., Mitre-Salazar, L.M., Mota-Palomino, R., Estructura geológica, gravimetría, sismicidad y relaciones neotectónicas regionales de la Cuenca de México [Geological structure, gravimetry, seismicity and regional neotectonic relations of the Basin of Mexico]. Universidad Nacional Autónoma de México, Instituto de Geología, Boletín 104, 1988 (in Spanish).

[12] Lozano-García, M.S., Ortega-Guerrero, B., Late Quaternary environmental changes of the central part of the Basin of Mexico; correlation between Texcoco and Chalco basins. Rev. Palaeobot. Palyno., 1998, 99, 77-93.

[13] Rudolph D., Herrera I., Yates R., Groundwater flow and solute transport in the industrial well fields of the Texcoco saline aquifer system near Mexico City. Geofis. Int., 1989, 28(2), 363408.

[14] Ovando-Shelley, E., Ossa, A., Santoyo, E., Effects of regional subsidence and earthquakes on architectural monuments in Mexico City. B. Soc. Geol. Mex., 2013, 65, 157-167.

[15] Ramos-Leal, J., Noyola-Medrano, C., Tapia-Silva, F., Aquifer vulnerability and groundwater quality in mega cities: Case of the Mexico Basin. Environ. Earth Sci., 2010, 61, 1309-1320.

[16] Gobierno de la Ciudad de México (GCDMX), Normas Técnicas Complementarias para Diseño y Construcción de Cimentaciones: Ciudad de México, México, Gaceta Oficial de la Ciudad México, 15 December 2017, 8-711 (in Spanish).

[17] Tavenas, F., Jean, P., Leblond, P., Leroueil, S., The permeability of natural soft clays. Part II: Permeability characteristics. Can. Geotech. J., 1983, 20(4), 645-660.

[18] Baligh, M.M., Levadoux, J.N., Consolidation after undrained piezocone penetration II: interpretation. J. Geotech. Eng.-ASCE, 1986, 112(7), 727-745.

[19] Hansbo, S., Design aspects of vertical drains and lime column installations. In: Southeast Asian Geotechnical Conference, SEAGS: Bangkok, Thailand, 1987, 8.1-8.12.

[20] Onoue, A., Consolidation of multilayered anisotropic soils by vertical drains with well resistance. Soils Found., 1988, 28(3), 75-90.

[21] Bergado, D., Asakami, H., Alfaro, M., Balasubramaniam, A., Smear effects of vertical drains on soft Bangkok clay. J. Geotech. Eng.-ASCE, 1991, 117(10), 1509-1530.

[22] Shogaki, T., Moro, H., Masaharu, M., Kaneko, M., Kogure, K., Sudho, T., Effect of sample disturbance on consolidation parameters of anisotropic clays. In: Int. Sym. on Compression and
Consolidation of Clayey Soils, Hiroshima, Japan, 1995, 561-566.

[23] Indraratna, B., Redana, I. W., Laboratory determination of smear zone due to vertical drain installation. J. Geotech. Geoenviron. 1998, 2(124), 180-184.

[24] Herrera I., Alberro J., León J., Chen B., Análisis de asentamientos para la construcción de los lagos del Plan de Texcoco: Ciudad de México, México [Settlement analysis for the construction of Plan de Texcoco Lakes: Mexico City, Mexico]. Instituto de Ingeniería, Universidad Nacional Autónoma de México, 1974 (in Spanish).

[25] Lucero-Rivera, J. R., Caracterización de la permeabilidad del subsuelo del ex Lago de Texcoco mediante pruebas de laboratorio [Characterization of subsoil permeability of the former Lake Texcoco through laboratory tests]. Masters thesis, Universidad Nacional Autónoma de México, Mexico, 2018 (in Spanish).

[26] United States Bureau of Reclamation (USBR), Procedure for Performing Field Permeability Testing by the Well Permeameter Method (USBR 7300-89). Earth Manual, Part 1, Earth Sciences and Research Laboratory Geotechnical Research, 1998.

[27] Chapuis, R.P., Overdamped slug test in monitoring wells: Review of interpretation methods with mathematical, physical, and numerical analysis of storativity influence. Can. Geotech. J., 1998, 35, 697-719.

[28] Association Française de Normalisation (AFNOR), Reconnaissance et essais, Essai d'eau LEFRANC [Recognition and tests, LEFRANC water test]. Norme Française NF P 94-132 Sols, 2000 (in French).

[29] Mayne, P.W., Synthesis 368 on Cone Penetration Testing: Stateof-Practice. Transportation Research Board, NCHRP Project 2005, Task 37-14, 2007.

[30] Levadoux, J.N., Baligh, M.M., Consolidation after undrained piezocone penetration I: Prediction. J. Geotech. Eng.-ASCE, 1986, 112(7), 707-726.

[31] Schmertmann, J.H., Guidelines for Cone Penetration Test (Performance and Design). Federal Highway Administration (FHWA), Report No. FWHA-TS-78-209, 1978.

[32] Parez, L., Fauriel, R., Le piezocone-ameliorations apportees a la reconnaissance des sols [Piezocone - Improvements to soil recognition]. Rev. Franç. Géotech., 1988, 44, $13-27$ (in French).

[33] Robertson, P.K., Sully, J.P., Woeller, D.J., Lunne, T., Powell, J.J.M., Gillespie, D.G., Estimating coefficient of consolidation from piezocone tests. Can. Geotech. J., 1992, 29(4), 539-550.

[34] Robertson, P. K., Estimating in-situ Soil Permeability from CPT y CPTu. In: Proceedings of the 2 nd International Symposium on Cone Penetration Testing, Pomona, CA, 2010.

[35] López-Acosta, N.P., Espinosa, A.L., Estimación de la permeabilidad en materiales finos mediante pruebas de disipación de presión de poro [Estimation of permeability in fine materials through pore pressure dissipation tests]. In: Memorias de la XXVIII Reunión Nacional de Ingeniería Geotécnica, SMIG: Mérida, México, 2016 (in Spanish).

[36] Levadoux, J.N, Baligh, M.M., Pore pressure during cone penetration in Clays. Dept. of Civil Engineering, Massachusetts Institute of Technology, Cambridge, Research Report R80-15, 1980.

[37] Freeze R.A., A stochastic-conceptual analysis of onedimensional groundwater flow in nonuniform homogeneous media. Water Res., 1975, 11(5), 725-41. 
[38] Hoeksema, R.J., Kitanidis, P.K., Analysis of the spatial structure of properties of the selected aquifers. Water Res., 1985, 21(4), 563-72.

[39] Sitar, N., Cawfield, J.D., Der Kiureghian, A., First-order reliability approach to stochastic analysis of surface flow and contaminant transport. Water Res., 1987, 23(5), 794-804.

[40] Griffiths, D.V., Fenton, G.A., Probabilistic analysis of exit gradients due to steady seepage. J. Geotech. Geoenviron., 1998, 124(9), 789-97.

[41] López-Acosta, N. P., Auvinet, G., Uncertainty in analyses of onedimensional steady-state seepage through random porous media. Probabilist. Eng. Mech., 2011, 26, 501-510.
[42] López-Acosta, N.P., Barba-Galdámez, D.F., Espinosa-Santiago, A.L., Choque-Mamani, P.I., Data on horizontal hydraulic conductivity of fine-grained soils of the former Lake Texcoco (Mexico). Data in Brief, 2018, 19, 1670-1682.

[43] Rovey, C.W., Cherkauer, D.S., Scale dependency of hydraulic conductivity measurements. Ground Water, 1995, 33(5), 769780 .

[44] Gwenzi, W., Hinz, C., Holmes, K., Philips, I.R., Mullins, I.J., Fieldscale spatial variability of saturated hydraulic conductivity on a recently constructed artificial ecosystem. Geoderma, 2011, 166, 43-56.

[45] Ronayne, M.J., Houghton, T.B., Stednick, J.D., Field characterization of hydraulic conductivity in a heterogeneous alpine glacial till. J. Hydrol., 2012, 458-459, 103-109. 